\title{
Study on Impact of the New Budget Law on Financial Management and Its Countermeasures
}

\author{
Biao Liü, a \\ ${ }^{1}$ Jiangxi Science \&Technology Normal University, Finance Department, Nanchang, Jiangxi, \\ 330013 \\ ${ }^{a}$ email
}

Keywords: Intensified Countermeasures, A New Budget Law, College Financial Management

\begin{abstract}
Starting January 1, 2015, our country will be promulgated the "People's Republic of China Budget Law." The budget law allows public and refine the budget be effectively strengthened, thus enabling expenditure even more standardized. Universities from financial management, the implementation of the new budget law on Financial Administration had multiple effects. This paper focuses on the impact of new budget law on Financial Administration, and further strengthen the proposed measures to provide some valuable reference proposal for the university to adapt to lift the financial management in the new budget law.
\end{abstract}

\section{Introduction}

Universities in the development process must strengthen management, university financial management is the overall management of the College particularly important aspect. But the current situation, most of our colleges and universities, there are some obvious problems yet in financial management, summed up include: the low efficiency of financial management, budget management are not standardized, and transparency of financial information is not high [1]. Under the new budget law background, for the optimization of Financial Management has provided an opportunity. From the optimization of College Financial Management and Improvement viewpoint, the paper "New Budget Law on Financial Administration and its countermeasures" to analyze significant.

\section{Effect of the new budget law on Financial Management Analysis}

To make the overall management of the College improved effectively, there will be a need to strengthen financial management at college. In the implementation of the new budget law background, college financial management received some positive impact. Specific impact performance is as follows:

For the new budget law, the detailed provisions of the budget, although so difficult budgeting increased to some extent, but the preparation of the budget in terms of refinement, put forward higher requirements. For example: accounting refinement to achieve the consistency of the budget and final accounts; another example: the implementation of a cash basis, and accrual to be introduced. The implementation of these systems are capable of making fine degree of budgeting has been effectively improved. Also, with the new budget law, the accounting also made for fine high requirements. For example: The new budget law on the use of funds focusing on stressed, requires appropriately reduce surplus carry-over funds, the time value of money and the rational use, and thus make money in the time span effectively promote optimal allocation [2]. In short, in the implementation of the new budget law, so Budgeting and Accounting degree of precision is improved effectively, so as to optimize the financial management of the College laid the foundation effective.

Among the new budget law, clearly states: "Budget is mainly made of a combination of two parts, one for the budget revenue; the other for the budget expenditures; for all revenue and expenditure of the government, it included in the budget which are necessary . "from the current situation, the type of budget revenue to cover the many colleges and universities, such as research funding income, tuition fees and financial allocations, and so on. Because there are insufficient College on budget 
management system, it is necessary to build a sound and efficient budget management system, and further to achieve full-caliber budget management, so that the budget management are not standardized, scientific status effectively prevent [3]. Under the new budget law imposed conditions, it is possible to implement a full-caliber budget management of colleges and universities are effectively promoted so that the integrity of the budget has been effectively improved, while the overall capacity of the financial sector has been effectively improved.

In the context of the new budget law, university financial management system even more transparent. Clearly, in the case of transparent system, monitoring system will be more prominent. At the same time, in the context of the new budget law, all kinds of income and expenditure universities have become more transparent, especially the "Three funds' transparency, transparency of financial management at college to make more significant [4]. In addition, the new budget law also allows the transparency of Universities debt has been effectively enhanced to ensure that the debt ratio controlled not only beneficial to the creditors, but also conducive to the further development of university financial management. All in all, the implementation of the new budget law in transparency college financial management effectively enhanced, thus contributing to the optimization and complete college financial management.

\section{College Financial Management Application of New Budget Law}

In the analysis process, we are recognizing that implementation of the new cloud algorithm, so that university financial management by the many positive effects. From the perspective of strengthening university financial management considerations, there is a need in the new algorithm cloud background, to take effective measures to make truly effective university financial management strengthened. Specific Measures to strengthen as follows:

Among the new budget law, the budget for the College Financial has been clearly defined, namely: to be refined for budget expenditures in various sectors. And, speaking for colleges and universities, to be combined with development of the times, to regulate the operation of the financial mechanism of universities to enhance the regularity of budget expenditure and scientific. To sum up, the need to improve the operation of the financial mechanism of University, its implementation method comprising: on the one hand, to strengthen the financial management of colleges and universities. Each department must report the data's real income and expenditure data. Based reporting period, staff need to remain relevant financial financial documents, so that the expenditure and revenue can be evidence-based. On the other hand, the need to build a comprehensive budget expenditure reporting system. Among the institutional budget expenditure reporting process to be clear, and to refine the various elements which, further refine the budget implementation methods into practice, in order to obtain a basis for the budget outcome. In addition, there is a need for examination and approval department and individual rights were clearly defined, to develop a reasonable, standardized program budget approval process to ensure the rational and scientific use of funds, and thus make financial flows more clear and reasonable.

To make college financial management in the application of the new budget law adaptability strong, it would be necessary to optimize the organizational structure of College Financial. For college financial structure, it will be due to changes in the financial pipeline targets and change. Under conditions based on the overall budget, the university budget management began to move toward an integrated management direction. Therefore, for colleges and universities, it is necessary to build an integrated organizational structure of the parties. First, a comprehensive budget management and oversight committee be set co-ordination led by the leadership of University of Finance and Economics, obligations and responsibilities of various departments in colleges and universities budget work need to be explicitly performed, the chief accountant of the implementation of the budget by the overall supervision of the program . Secondly, the financial position of the grass-roots scientific settings, and various university authorities formed butt, make sure to contact the various departments during the implementation of the overall budget between enhanced. Finally, multi-lateral ties finance various functional departments to strengthen, to evade responsibility and making organizational efficiency weakened condition fully avoid further enables 
organizations to effectively optimize the financial structure of college, thus contributing to improving financial management at college.

In college financial management, the finance staff plays a very important role, its financial management in colleges and universities for the implementation of the main person. Therefore, it is necessary to finance the operational capacity of the staff will be improved, so that the university financial management can more effectively adapt to the basic requirements of the new budget methodology. On the one hand, university financial management leaders need to set an example, to strengthen the financial education of staff, finance staff organize further financial regulations and financial accounting knowledge and learning, so that the financial expertise of the staff effectively supplement and update to accommodate budget the new law requires. On the other hand, it is for colleges and universities need to strengthen the training of finance staff, so that finance staff trained to fully understand the new budget law, and understand modern financial management techniques. And, to be in the training process, focusing on development of managerial skills, so that the overall quality of the staff involved in training to effectively increase [5]. In addition, there is a need in the training process, combined with incentives and evaluation mechanisms, training of personnel involved in the performance of outstanding positive incentive; and through the evaluation, the evaluation of qualified personnel available for employment office; and for the evaluation of unqualified personnel, you need to further training, job tenure until the examination before clearance, thus enabling the overall quality of financial ability of staff to a large extent be effectively improved, further lay the foundation for effectively improve financial management at college level.

\section{Conclusion}

By exploring this article, Financial Management College Recognizing the current situation facing yet some of the more obvious problems. However, in the implementation of the new budget law background, making the development of financial management at college to get an effective opportunity. To sum up, the impact of the new budget law on Financial management is a significant order for the university financial management more adapted to the new budget law, there is a need sound operational mechanism college financial, organizational structure College Financial to be optimized as well as efforts to improve the finance staff overall quality. Believed to be improved from the above aspects, financial management colleges and universities will be able to be effectively improved, further lay a solid foundation for the development of universities.

\section{References}

[1] Yan Tingmiao. New "Budget Law" on the university budget management and its countermeasures [J]. Journal of Xinyang Agricultural College, 2015,02: 67-68 + 71 .

[2] Yan Tingmiao. impact of the new budget law on University Management [J]. Friends of Accounting, 2015, 14: 88-91.

[3] Sun Shengzhe. New budget law on the management of financial institutions affect countermeasures [J]. Managers, 2015, 36: 122.

[4] Kuo Mingxue. A new budget law on hospital financial accounting management and the Countermeasures [J]. Financial sector (Academic Edition), 2016, 04: 186.

[5] Zang Jian. New budget law on financial institution management and the Countermeasures [J]. contemporary accounting, 2016, 02: 26-27. 